\title{
PREVALENCE STUDY ON BRUCELLOSIS IN SOME RUMINANTS SLAUGHTERED OUT OF ABATTOIRS IN ASSIUT GOVERNORATE
}

\author{
S.H. AL-HABATY*; K.A. ABUO-GAZIA ${ }^{* *}$ and M.A.M. AMMAR* \\ *Animal Health Research Institute, Assiut regional Lab. (AHRI), Egypt. \\ ***Animal Reproduction Research Institute (ARRI), Giza, Egypt. \\ Email: mahmoud2014eg@yahoo.com
}

\section{ABSTRACT}

Received at:10/11/2014

Accepted: 15/12/2014
In this study, 482 serum and tissues samples including spleen and lymph nodes were collected from cattle (215), buffaloes (103), sheep (105) and goats (59), which had been slaughtered out of abattoirs in different localities in Assiut Governorate. The serum samples were examined for the detection of antibodies against Brucella spp. The results of screening tests Buffer acidified plate antigen test (BAPAT) and Rose Bengal plate test (RBPT) gave 36 seroreactive animals by incidence of $10.23 \%$ in cattle, $2.91 \%$ in buffaloes, $7.61 \%$ in sheep and $5.08 \%$ in goats, respectively. All positive serum samples were further retested by Standard serum agglutination test (SAT), Rivanol test (RIVT) and indirect enzyme linked immunosorbent assay (ELISA) as confirmatory tests. SAT gave $90.9 \%$ in cattle and $100 \%$ in buffaloes while RIVT gave $86.3 \%$ in cattle and $100 \%$ in goats of serorective animals. Moreover, ELISA gave $95.4 \%$ in cattle, $100 \%$ in buffaloes, $87.5 \%$ in sheep and $100 \%$ in goats of the seroreactive animals. Eleven isolates $(30.3 \%)$ of brucella melitensis biovar 3 were recovered from 36 seroreactive animals. These isolates represent $6(27.3 \%)$ for cattle, $1(33.3 \%)$ for buffaloes, 3(37.5\%) for sheep and $1(33.3 \%)$ for goats. In conclusion, Brucella melitensis was wide spread in ruminants slaughtered out of abattoirs in Assiut Governorate which cause a serious infection in human and animals.

Key words: Prevalence - brucellosis - ruminants- slaughtered -out - abattoirs - Assiut

\section{INTRODUCTION}

Brucellosis is an important re-emerging zoonosis with worldwide distribution. It stills an uncontrolled serious public health problem in many developing countries including Egypt (Mantur and Amarnath, 2008 and Samaha et al., 2009). Although brucellosis has been controlled in most industrialized countries, it remains a major problem in the Mediterranean region, western Asia, Africa, and Latin America (Pappas et al., 2006). Brucellosis causes appreciable economic losses in livestock industry because of abortions, retained placenta, decreased milk production, sterility in males due to orchitis and veterinary care in cattle, sheep and goat as well as treatment costs in human (Corbel 1997 and Adams, 2002). Unfortunately, the applied control measures may not be capable of reducing the levels of infection in ruminants (Hegazy et al., 2009). Brucellosis for several decades has been recognized as a significant public health problem which includes chills, fever, malaise and headache, requiring prolonged treatment (Korman, 1988). In the Middle East, Benkirane (2006) suggested that its incidence is increasing in ruminants and humans.
Brucella melitensis biovar 3 is considered to be the predominant species of brucella isolated from humans and animals in Egypt (Refai, 2002). Outbreaks in cattle due to $B$. melitensis have become a worldwide emerging problem particularly difficult to control due to lack of knowledge on the epidemiolgy in this host species and of uneffective vaccination (Alvares et al., 2011). Prevalence of brucellosis in cattle and buffaloes based on a survey studies published between 1948 and 2009 in Egypt nearly was $5.4 \%$ by BPAT (Gwida et al., 2010). The study by Kaoud et al. (2010) revealed that prevalence of Brucella among herds of cattle, sheep and goats in certain Governorates using RBPT were $21.6 \%, 26.6 \%$ and $18.8 \%$, respectively. When RBPT positive samples were subjected to ELISA test, the percentages were $17.2 \%, 21.2 \%$ and $14.5 \%$, respectively. Moreover, in a recent study the incidence of brucellosis was $8 \%$ in cattle, $1 \%$ in buffaloes and $4 \%$ in sheep, Horton et al. (2014). Incidence of brucellosis in Assiut Governorate was ranged between $0.57 \%$ to $1.34 \%$ in cattle by Abedel-Hafeez (1996) and Koriem et al. (2013), in buffalo $3.03 \%$, to $3.35 \%$ by Samaha et al. (2008) and Koriem et al. (2013), in sheep $1.1 \%$ to $1.35 \%$ by Sedeek (1999) and Abedel-Hafeez et al. (2001) and finally in goats the incidence ranged 
between $0.27 \%$ to $0.94 \%$ by Nashed (1977) and Mohammed (2001).

Bacterial load in animal muscle tissues is low but consumption of under cooked traditional delicacies such as liver has been implicated in human infection (Tikare et al., 2008). The transmission of brucella infection and its prevalence in a region depends upon several factors like food habits and methods of processing (Mantur et al., 1996). Unsafe butchering is considered to be one of the major risk factors for human infection with Brucella species. The organism could be detected in swabs collected from butchers hands, knives, tables and meat displayed for sale (Uche and Agbo, 1985). Those with a professional risk of acquiring infection include livestock producers, abattoir workers, shepherds, farmers, and veterinarians. The much higher seroprevalence rate has been also noted in abattoir workers (Barbuddhe et al., 2000, Mantur andAmarnath, 2008). Unhygienic disposal of slaughtered animals parts i.e. blood, tissues, gravid uterus, infected fluid, fetal membranes as well as manure interferes with brucella controlling programs (Ramos et al., 2008).

It was found that BAPAT and RBPT serological tests gave the highest rate of sensitivity that guides us to use these tests as screening tests on animals brucellosis. RIVT. showing the highest rate of specificity that bearing in mind the BAPAT and RBPT positive samples should be confirmed by this test, Montasser et al. (2011). ELISA has been reported as a very sensitive and specific test for the diagnosis of brucellosis (Raúl et al., 2005). The gold standard that confirms the presence of the diseases is the isolation, identification and biotyping of the bacterial agent (Cunningham (1977) and Alton et al., 1988). On the other hand Hamdy (1997) revealed that the definitive diagnosis for brucellosis requires the recovery of the organism but it is difficult due to the fastidious nature of organism and in case of mild infection. Therefore, diagnosis has been based mostly on the results of serological tests. For brucellosis the Serological tests detect the presence of anti-lipopolysaccharide (anti- LPS) antibodies, measure total antibodies or measure the level of different immunoglobulins (Wright and Nielsen 1990). Usually a battery of tests is used for serologic testing of brucellosis as there is no single test capable for detecting all infected animals (Ibrahim et al., 1999). Tests currently used for the serological diagnosis of infections in sheep and goats were initially developed the same for the diagnosis of infections in cattle (SANCO 2001).

The present work aimed to document the frequency of brucellosis among different ruminants slaughtered out of abattoirs in Assiut Governorate through performing screening and confirmatory serological tests and isolation of brucella organism from tissues of the slaughtered animals.

\section{MATERIALS and METHODES}

\section{1- Collection of samples:}

Serum and tissue samples (lymph nodes and spleen) were aseptically collected from (482) Egyptian native breed animal species which slaughtered out of abattoirs in different localities at Assiut Governorate as explained in Table (1). These samples were collected during the period from January 2013 to July 2014.

Table 1: Samples distribution from different localities in Assiut Governorate and their sex of slaughtered food animals.

\begin{tabular}{cccccc}
\hline Animal species & No. of samples & \multicolumn{2}{c}{ Locality } & \multicolumn{2}{c}{ Sex } \\
\hline & & North Assiut & South Assiut & Male & Female \\
\hline Cattle & 215 & 150 & 65 & 0 & 215 \\
\hline Buffaloes & 103 & 18 & 85 & 5 & 98 \\
\hline Sheep & 105 & 30 & 75 & 12 & 93 \\
\hline Goats & 59 & 24 & 35 & 25 & 457 \\
\hline Total & 482 & 222 & 260 & 8 & 45 \\
\hline
\end{tabular}

\section{2- Serological tests:}

The collected serum samples (482) were examined by BAPAT and RBPT as screening tests. Then all positive serum samples were further retested by SAT, RIV T. and ELISA as quantitative confirmatory tests. The antigens of BAPAT, RBPT, SAT and RIVT. were supplied by Veterinary Serum and Vaccine Research Institute - Abbasia, Cairo- Egypt and performed according to Alton et al. (1988). ELISA antigen was supplied from Synbiotics Europe 2, rue A
- Fleming 69007 Lyon -France. Serum samples was performed by ELISA as mentioned by Jimenez et al. (1992).

\section{3- Bacteriological examination:}

Supramammary and inguinal lymph nodes and parts from spleen were collected from 482 animal species at the time of slaughter. Samples were directly taken to the laboratory in ice-box and kept in deep freezing $\left(-20^{\circ} \mathrm{C}\right)$ until serological tests were performed. Tissue 
samples from the seropositive animals (36) were examined bacteriologically according to (Alton et al., 1975 and Magwedere, 2011). Tissue samples were thawed over night at $5^{\circ} \mathrm{C}$. The lymph node was sliced into half exposing the inner surface, which was minced for 2 to $3 \mathrm{~min}$. with a sterile scalpel. The content of lymph node was mixed with an equal volume of isotonic phosphate-buffered saline $(\mathrm{pH}$ 6.3) and blended in a laboratory blender for $5 \mathrm{~min}$. Fifty grams of spleen was mixed with $100 \mathrm{~mL}$ of isotonic phosphate-buffered saline $(\mathrm{pH}$ 6.3) and blended in a laboratory blender for $5 \mathrm{~min}$. The macerated tissue suspension was spread with a sterile cotton swab over the entire surface of agar plates of Farrell's medium blood agar base (oxoid) supplemented with $10 \%$ equine serum, $1 \%$ glucose and brucella selective supplement (Oxoid). The plates were incubated at $37^{\circ} \mathrm{C}$ in an aerobic atmosphere containing $10 \% \mathrm{CO}_{2}$. Cultured plates were examined for growth on day 4 and daily for 4 weeks. Suspected colonies were subcultured on Brucella agar slants (Oxoid) for further identification. The isolates were identified according to morphologic characteristics, microscopic appearance, slide agglutination tests with (anti-S brucella serum, anti-R brucella serum), Lactose fermentation, growth on MacConkey agar; Haemolysis on blood agar, Motility at $37^{\circ} \mathrm{C}$, Oxidase, Urease, Nitrate reaction, sensitivity to dyes and citrate utilization.

\section{RESULTS}

The obtained results were recorded in tables 2- 5

Table 2: Seroprevalence of brucellosis in different animal species using screening tests (BAPAT and RBPT).

\begin{tabular}{cccccc}
\hline & & \multicolumn{5}{c}{ Screening tests } \\
\cline { 3 - 6 } $\begin{array}{c}\text { Animal } \\
\text { species }\end{array}$ & No. of samples & \multicolumn{3}{c}{ RBPT } & \multicolumn{3}{c}{ BABAT } \\
\cline { 3 - 6 } & & + Ve & +Ve & $\%$ \\
\hline Cattle & 215 & 22 & 10.23 & 21 & 9.76 \\
\hline Buffaloes & 103 & 3 & 2.91 & 3 & 2.91 \\
\hline Sheep & 105 & 8 & 7.61 & 8 & 7.61 \\
\hline Goats & 59 & 3 & 5.08 & 3 & 7.61 \\
\hline Total & 482 & 36 & 7.46 & 35 & 7.26 \\
\hline
\end{tabular}

Table 3: Seroprevalence of brucellosis in positive reactor animals detected by confirmatory tests.

\begin{tabular}{|c|c|c|c|c|c|c|c|c|c|c|c|}
\hline \multirow{3}{*}{$\begin{array}{l}\text { Animal } \\
\text { species }\end{array}$} & \multirow{3}{*}{ No. of samples } & \multicolumn{4}{|c|}{ Screening tests } & \multicolumn{6}{|c|}{ Confirmatory tests } \\
\hline & & \multicolumn{2}{|c|}{ BAPAT } & \multicolumn{2}{|c|}{ RBPT } & \multicolumn{2}{|c|}{ SAT } & \multicolumn{2}{|c|}{ RIVT } & \multicolumn{2}{|c|}{ ELISA } \\
\hline & & $+\mathrm{Ve}$ & $\%$ & $+\mathrm{Ve}$ & $\%$ & $+\mathrm{Ve}$ & $\%$ & $+\mathrm{Ve}$ & $\%$ & $+\mathrm{Ve}$ & $\%$ \\
\hline Cattle & 22 & 22 & 100 & 21 & 95.4 & 20 & 90.9 & 19 & 86.3 & 21 & 95.4 \\
\hline Buffaloes & 3 & 3 & 100 & 3 & 100 & 3 & 100 & 2 & 66.6 & 3 & 100 \\
\hline Sheep & 8 & 8 & 100 & 8 & 100 & 6 & 75 & 5 & 62.5 & 7 & 87.5 \\
\hline Goats & 3 & 3 & 100 & 3 & 100 & 2 & 66.6 & 3 & 100 & 3 & 100 \\
\hline Total & 36 & 36 & 100 & 35 & 97.2 & 31 & 86.1 & 29 & 80.5 & 34 & 94.4 \\
\hline
\end{tabular}


Table 4: Seroprevalence of brucellosis in different animal species in relation to their sex and locality based on ELISA.

\begin{tabular}{|c|c|c|c|c|c|c|c|c|c|c|c|c|c|}
\hline \multirow{3}{*}{$\begin{array}{c}\text { Animal } \\
\text { species }\end{array}$} & \multirow{3}{*}{ Total } & \multicolumn{6}{|c|}{ Locality } & \multicolumn{6}{|c|}{ Sex } \\
\hline & & \multicolumn{3}{|c|}{ North Assiut } & \multicolumn{3}{|c|}{ South Assiut } & \multicolumn{3}{|c|}{ Female animals } & \multicolumn{3}{|c|}{ Male animals } \\
\hline & & $\begin{array}{c}\text { No. of } \\
\text { samples }\end{array}$ & $+\mathrm{Ve}$ & $\%$ & $\begin{array}{c}\text { No. of } \\
\text { samples }\end{array}$ & $+\mathrm{Ve}$ & $\%$ & $\begin{array}{c}\text { No.of } \\
\text { samples }\end{array}$ & $+\mathrm{Ve}$ & $\%$ & $\begin{array}{c}\text { No. of } \\
\text { samples }\end{array}$ & $+\mathrm{Ve}$ & $\%$ \\
\hline Cattle & 215 & 150 & 18 & 12.0 & 65 & 3 & 4.61 & 0 & 0 & 0 & 215 & 21 & 9.76 \\
\hline Buffaloes & 103 & 18 & 1 & 5.5 & 85 & 2 & 2.35 & 5 & 0 & 0 & 98 & 3 & 3.06 \\
\hline Sheep & 105 & 30 & 2 & 6.6 & 75 & 5 & 6.66 & 12 & 1 & 8.3 & 93 & 6 & 6.45 \\
\hline Goats & 59 & 24 & 1 & 4.1 & 35 & 2 & 5.7 & 8 & 0 & 0 & 51 & 3 & 5.8 \\
\hline Total & 482 & 222 & 22 & 9.9 & 260 & 12 & 4.6 & 25 & 1 & 4 & 457 & 33 & 7.2 \\
\hline
\end{tabular}

Table 5: Prevalence of brucella organism in seroreactive animals.

\begin{tabular}{cccc}
\hline Animal species & $\begin{array}{c}\text { Total serologically } \\
\text { positive }\end{array}$ & \multicolumn{2}{c}{ Total bacteriologically positive } \\
\cline { 3 - 4 } & 22 & No. & $\%$ \\
\hline Cattle & 3 & 6 & 27.3 \\
\hline Buffaloes & 8 & 1 & 33.3 \\
\hline Sheep & 3 & 3 & 37.5 \\
\hline Goat & 36 & 1 & 33.3 \\
\hline Total & & 11 & 30.3 \\
\hline
\end{tabular}

\section{DISCUSSION}

The principal objective of using serological tests in control and eradication programs of brucellosis is to detect infected animals that may cause spread of the disease. Unfortunately, there is no single test can identify all infected animals at all stages of the disease, therefore a combination of serological tests should be included to reduce the number of both false negative and false positive serological reactions (Cordes and Carter, 1979).

In the present study, Table (2) shows the incidence of brucellosis among slaughtered animals out of abattoirs in Assiut Governorate. By using screening tests BAPAT and RBPT the incidence of brucellosis were $10.23 \%, 9.76 \%, 2.91 \%, 2.91 \%, 7.61 \%, 7.61 \%$, $5.08 \%$ and $5.08 \%$ in cattle, buffalo, sheep, and goats, respectively. This result was nearly similar to that reported by Montasser et al. (2001) who recorded that the incidence among cattle was $7.5 \%, 10 \%, 7.75 \%$, $9 \%, 7.12 \%$ and $7.12 \%$ by using CFT, BAPAT, RBPT, SAT, MET and RIVT, respectively. On the other hand, this result was much higher than that recoded by Koriem et al. (2013) who found that the incidence of Brucella in cattle slaughtered in governmental abattoirs was $1.34 \%$. On contrast our result is lower than that recorded by Kaoud et al. (2010), Holt et al. (2011) and Horton et al. (2014).

Regarding buffaloes results revealed that the prevalence was $2.91 \%$ by both BAPAT and RBPT. The obtained result was nearly similar to that recorded by Samaha et al. (2008) but lower than that reported by Ali and Mahdey (2010), Holt et al. (2011) and daSilva et al. (2014) who cited the infection rate ranged between $7.6 \% 15.5 \%$ and $12.4 \%$. The obtained results revealed that the incidence of infection was higher in cattle than in buffalo. This may be due to the fact that buffaloes have more resistant to the disease than cattle (Fosgate et al., 2011).

Concerning sheep the prevalence of brucellosis in the persent study was $7.61 \%$ by BAPAT and RBPT. This result was much higher than those cited by Sedeek (1999) and Abdel-Hafeez et al. (2001) but lower than that reported by Hegazy et al. (2011). Our results in goats showed that the prevalence of brucellosis was $5.08 \%$ by BAPAT and RBPT. This was nearly the same which was reported by Montasser et al. (2011), but much higher than Nashed (1977) and Abd-ElKader (1996) who pointed that the incidence was 0.82 $\%$ and $0.33 \%$ using RBPT screening test. Moreover, high prevalence rate was noticed in sheep and goat by 
Kaoud et al. (2010). The high ratio of brucellosis in sheep and goats may be due to free grazing and movement of these flocks which contribute to the wide distribution of brucellosis in these animals and to other animal species (Mantur and Amarnath 2008).

In Table (3) the results indicated that BAPAT gave of $100 \%$ in all tested seroreactor animals while RBPT gave $95.4 \%$ in cattle. This finding was in agreement with Angus and Barton (1984) and Montasser et al. (2012). In addition to Gall and Nielsen (2004) who mentioned that BAPAT was more sensitive and accurate than other conventional tests for detection of brucella in bovine serum. This may be due to the instability of some antigen preparations used in the other tests as RBPT which may deteriorate when repeatedly cycled between refrigerator and room temperature during use (MacMillan, 1990).

The SAT gave of $90.9 \%$ in cattle and $100 \%$ in buffaloes while RIVT gave $86.3 \%$ in cattle and $100 \%$ in goats of the seroreactive animals. Moreover, ELISA gave $95.4 \%$ in cattle, $100 \%$ in buffaloes, $87.5 \%$ in sheep and $100 \%$ in goats of the seroreactive animals.

The overall percentage of seropositive reactors detected by BAPAT were (100\%), RBPT (97.2\%), SAT $(86.1 \%)$, RIVT. $(80.05 \%)$ and ELISA $(94.4 \%)$. These results was in agreement with the finding of Abdoel and Smit (2007) and Montasser et al. (2012). The radical change in the incidence of the serological tests between screening tests (BAPAT and RBPT) and confirmatory tests (SAT, RIV.T. and ELISA tests) was due to the activity of specific and non-specific antibodies (Alton et al., 1988). Our finding revealed that RIVT. and ELISA are good confirmatory tests for diagnosis of caprine brucellosis this also reported by Mohammed (2001). Moreover, ELISA consider an excellent test for diagnosis of brucellosis in ruminants which has high sensitivity and specificity which agree with the finding of Raúl et al. (2005) and Montasser et al. (2012).

The obtained results in Table (4) showed that cattle and buffalo which slaughtered at north Assiut had more incidence of brucellosis than that of south Assiut. This result was coincides with that obtained by Montasser et al. (2011) and Koriem et al. (2013). Moreover, in Table (4) showed a high incidence in female animals than that of male animals. Similar result was recorded by Isloor et al. (1998) and Junaidu et al. (2011). The high ratio in seroreactive female animals in the present study may be due to most of these animals were female population, senile with a history of reproductive disorders and or emaciated as a mainly cause for culling. In the same manner Kazi et al. (2005) noted that the antibody titer against Brucella appears to be associated with the age as young female animals may be harbor the organism without expressing any detectable antibody till first parturition or abortion.

Taking into consideration that it is not always possible to recover brucella organisms from all organs of all infected animals also negative bacteriological investigation dose not exclude the presence of brucellosis as pointed out by Robertson et al. (1977). In Table (5) 11 isolates of brucella melitensis biovar 3 were recovered from 36 seroreactive animals form their lymph nodes and spleen. These isolates represent $6(27.3 \%)$ for cattle, 1 $(33.3 \%)$ for buffaloes, $3(37.5 \%)$ for sheep and 1 $(33.3 \%)$ for goats. Moreover, the overall mean isolation rate was $30.5 \%$ in relation to the seroreactive animals. Our results nearly similar to Esmaeil et al. (2008) and Al-Farwachi et al. (2010) who isolated 4 out of 12 seropositive samples $(33.3 \%)$. On the other hand, our results is higher than that reported by Salem and Hosein (1990) but was lower than that cited by Ali and Mahdey (2010) and Montasser et al. (2011) who their isolation rate reached to $50 \%$ and $38.3 \%$, respectively from spleen lymph nodes.

\section{CONCLUSION}

Brucella melitensis was wide spread in ruminants slaughtered out of abattoirs in Assiut Governorate. The absence of pre and post mortem examination and unhygienic disposal of blood, genital organs and infected lesions in out abattoir slaughter complicate the situation. Strict control measures should be taken by the Veterinary authorities to prevent the slaughtering out of abattoirs. Thus control the spreading of brucellosis infection in human and animals as well as success of eradication programs.

\section{REFERENCES}

Abd-El-Kader, H.A. (1996): Serological study of caprine brucellosis in Assiut Governorate. Assiut Vet. Med. J. 36 (71) 9-16

Abdoel, T.H. and Smits, H.L. (2007): Rapid latex agglutination test for the serodiagnosis of human brucellosis. Diagnostic microbiology and infectious disease. 57(2) 123-128.

Abedel-Hafeez, M.M. (1996): A serological study on brucella infection among cattle in Assuit Governorate. Assiut Vet. Med. J. 36 (71) 1- 8.

Abedel-Hafeez, M.M.; Abd-El-Kder, H.A.; Bastawrows, A.F.; Ail, A.A and Sedeek, S. R. (2001): Zoonotic importance of brucellosis among farm animals andveterinary field employees at Assiut Governorate. Assiut Vet. Med. J. 44 (88) 119-134.

Adams, L.G. (2002): The pathology of brucellosis reflects the outcome of the battle between the 
host genome and the Brucella genome. Vet. Microbiol. 90: 553-561.

Al-Farwachi, M.I.; Al-Badrani, B.A. and Al-Nima, T.M. (2010): Testing of brucella antigen in the aborted ovine fetal stomach contents using a modified ELISA test. Iraqi J.V.Sc. 24 (1) 1 - 4.

Ali, Fatma, H.M. and Mahdey, E.M. (2010): Incidence of Brucella Species in Slaughtered Food Animals and its Edible Offal at Benisuef, Egypt. Global Veterinaria 5 (5): 248-254.

Alton, G.G.; Jones, L.M. and Piets, D.E. (1975): Laboratory techniques in brucellosis, 2nd Edition. FAO/ WHO, Geneva.

Alton, G.G; Jones, L.M.; Angus, R.D. and Verger, J.M. (1988): Techniques for the Brucellosis Laboratory. INRA, Paris.

Alvares, J.; Saez, J.; Garcia, N.; Serrat, C.; PérezSancho, M; Gonzalez, S.; Ortega, M.; Gou, J.; Carbajo, L.; Garrido, F.; Goyache, J. and Dominguez, L. (2011): Management of an outbreak of brucellosis due to $B$. melitensis in dairy cattle in Spain. Res. Vet. Sci. 90: 208-211.

Angus, R.D. and Barton, C.E. (1984): The production and evaluation of a buffered plate antigen for use in a presumptive test for brucellosis. In Proc. $3^{\text {rd }}$ International Symposium on brucellosis, Algeria. Dev. Bio. Standard, 56, 349-356.

Barbuddhe, S.B.; Kumar, P.; Malika, S.V.; Singh, D.K. and Gupta, L.K. (2000): Seropositivity for intracellular bacterial infections among abattoir associated personnels; J. Commun. Dis. 32: 295-299.

Benkirane, A. (2006): Ovine and caprine brucellosis: Worled distribution and control/ eradication strategies in West Asia/ North Africa Region. Small Rumin. Res., 62: 19-25.

Corbel, M.J. (1997): Brucellosis: an overview. Emerg. Infect. Dis.3, (2), 213.

Cordes, D.O. and Carter, M.E. (1979): Persistence of Brucella abortus infection in six herds of cattle under brucellosis eradication. New Zealand Veterinary Journal, 27: 255-259.

Cunningham, B. (1977): A difficult disease called brucellosis. An international symposium, Taxes A and M. Univ. press, Collage station, USA., pp: 11-20.

DaSilva, J.P.; Rangal, C.P.; Da Fonseca, A.H; De Moris, E. and Barbosa, J.D. (2014): Serological survey and risk factors for brucellosis in water buffaloes in the states of Para, Brazil. Trop. Ainm Health Prod. 46 (2) 385-389.

Esmaeil, Z.; Abdollah, E. and Mehran, Y. (2008): Isolation and identifection of brucella organisms in Iran. J. Clinic Infectious Disease, 3 (4) 185-188.

Fosgate, G.T.; Diptee, M.D.; Ramnanan, A. and Adesiyun, A.A. (2011): Brucellosis in domestic water buffalo (Bubalusbubalis) of Trinidad and Tobago with comparative epidemiology to cattle. Trop. Anim. Health Prod. 43(8): 1479- 1486

Gall, D. and Nielsen, K. (2004): Serological diagnosis of bovine brucellosis: a review of test performance and cost comparison. Rev. Sci. Tech. of Int. Epiz. 23 (3) 989-1002.

Gwida, M.; Al Dahouk, S.; Melzer, F.; Rosler, U.; Neubauer, H. and Tomaso, T. (2010): Brucellosis-Regionally Emerging Zoonotic Disease? Croat Med. J. 51(4) 289-295.

Hamdy, M.E.R. (1997): Correlation between humeral and cellular immune response in dairy cows naturally infected with brucella abortus. Egypt. Vet. Med. Ass., 57(1) 331-349.

Hegazy, Y.M.; Ridler, A.L. and Guitian, F.J. (2009): Assessment and simulation of the implementation of brucellosis control program in an endemic area of the Middle East. Epidemiol. Infect. 137: 1436-1448.

Hegazy, Y.M.; Moawad, A.; Osman, S. and Ridler, A. (2011): Ruminant brucellosis in the Kafr Eheikh Governorate of the Nile Delta, Egypt: prevalence of neglected zoonosis. Negl. Trop. Dis. 5 (11)944-951.

Holt, H.R.; Eltholth, M.M.; Hegazy, Y.M.; El-Tras, W.F.; Tayel, A.A. and Javier, G. (2011): Brucella spp. infection in large ruminants in an endemic area of Egypt: cross-sectional study investigating seroprevalence, risk factors and livestock owner's knowledge, attitudes and practices. Public Health 11: 341.

Horton, K.C.; Wasfy, M.; Samaha, H.; AbdelRahman, B.; Safwat, S.; Abdel Fadeel, M.; Mohareb, E. and Dueger, E. (2014): Serosurvey for zoonotic viral and bacterial pathogens among slaughtered livestock in Egypt. Vector Borne Zoonotic Dis. 14(9): 633-639.

Ibrahim, K.A.; EL-Sheary, M.N.; El-Shreif, A.M. and Youssif, A.M. (1999): Investigation of the relative sensituvty and specifusty of some commonly used Brucllosis serological tests. 5th. Sci. Cong. Egypt Soci. Cattle Dis., 112-114.

Isloor, S.; Renukaradhya, G.J. and Rajasekhar, M. (1998): A serological survey of bovine brucellosis in India. Rev. Sci. Tech. 17(3)781-785.

Jimenez de Bagues, M.P.; Marin, C.M.; Blasco, J.M.; Moriy, I. and Gamazo, C. (1992): An ELISA with Brucella lipopolysaccharide antigen for the diagnosis of $B$. melitensis infection in sheep and for the evaluation of serological responses following subcutaneous or conjunctival B. melitensis strain Rev1vaccination. Vet. Microbiol. 30: 233-241.

Junaidu, A.U.; Oboeghlem, S.I. and Salihu, M.D. (2011): Serological survey of brucella 
antibodies in breeding herds. J. Microbiol. Biotech. Res. 1(1) 60-65.

Kaoud, H.A.; Manal. M. Zaki; El-Dahshan, A.R. and Shimaa, A. Nasr (2010): Epidemiology of Brucellosis Among Farm Animals. Nature and Science 8(5) 190-197.

Kazi, M.; Amin, R.; Bahman, M.B.; Rahman, M.S.; Han, J.; Park, and Chae, J. (2005): Prevalence of antibodies in sera of cows in Bangladesh. J.Vet. Sci.6: 223-226.

Koriem, A.M.; AL-Habaty, S.H.; Makar, N.A. and Abd-El-kader, H.A. (2013): Seroprevalence of Brucellosis in slaughtered animals at Assiut governorate. Assiut Vet. Med. J. 59 (137) 72-76.

Korman, S.; Srugo, I.; Tal, Y.; Jaffe, M.; Cahane, Z. and Wellish, G. (1988): Subacute meningitis caused by brucella, a diagnostic challenge. Eur. J. Ped.148: 120-121.

MacMillan, A. (1990): Conventional serological tests. Int. Animal brucellosis (Nielson K. and Duncan J.R. eds). CRC Press Boca Raton, 153-197.

Magwedere, K.; Bishi, A.; Tjipura-Zaire, G.; Eberle, G.; Hemberge, Y.; Hoffman, L.C. and Dziva, $F$. (2011): Brucellae through the food chain: the role of sheep, goats and springbok (Antidorcus marsupialis) as sources of human infections in Namibia. J. S. Afr. Vet. Assoc. 82 (4)1019.

Mantur, B.G. and Amarnath, S.K. (2008): Brucellosis in India - a review; J. Biosci. 33: 539-547.

Mantur, B.G.; Mangalgi, S.S. and Mulimani, M. (1996): Brucella melitensis sexually transmissible agent. Lancet, 347: 1763.

Mohammed, K.A.S. (2001): Diagnostic studies on caprine brucellosis in Assiut Governorate. Master Thesis, Faculty of Vet. Med. Assiut. Univ.

Montasser, A.M.; Hamdy, M.E.; El-Bayoumy, E.M. and Khoudeir, R.M. (2001): Bacteriological profile of Brucella isolated from cattle in Egypt. Proc. $6^{\text {th }}$ Sci. Ong. Society for cattle diseases. Assuit, pp: 136-170.

Montasser, A.M.; Khoudair, M.R.; Soliman, S.H. and Eman, A. Khairy (2012): Evaluation of Immunochromatographic Assay for Serodiagnosis of Brucella among Cattle, Sheep and Goats in Egypt. Global Veterinaria 8 (5): 511-518.

Montasser, A.M.; El-Bayoumy, E.M.; Abdul-Raouf, U.M. and. Mohamad, H.A. (2011): Efficiency of Serological Tests for Detection of Brucellosis in Ruminant at South Provinces of Egypt. Global Veterinaria 6 (2) 156-161.

Nashed, S.M. (1977): Brucellosis in Upper Egypt (Assiut Governorate) in cattle, buffaloes, sheep goats, and its relation to public health. Ph.D. Vet. Thesis, Fac. Vet. Med., Cairo Univ.
Pappas, G.; Papadimitriou, P.; Akritidis, N.; Christou, L. and Tsianos, V. (2006): The new global map of human brucellosis .Lancet Infect Dis. 6: 91-99.

Ramos, T.R.R.; Junior, J.W.P; Sobrinho, P.A.M.; Santana, V.L.A.; Guerra, N.R; Melo, L.E.H. and Mota, R.A. (2008): Epidemiological aspects of an infection by Brucella abortus in risk occupational groups in the microregion of Araguaina, Tocantins. Braz J Infect Dis; 12: 133-138.

Raúl, C.M.; Jaime, P.M; Muñ, J.M.; María J.G; Clara, M.M.; Ignacio, M. and Blasco, J.M. (2005): Specificity dependence between serological tests for diagnosing bovine brucellosis in Brucella-free farms showing false positive serological reactions due to Yersinia enterocolitica O:9. Can. Vet. J. 46: 913-916.

Refai, M. (2002): Incidence and control of brucellosis in the Near East region. J. Vet. Microbiol. 90(1-4): 81-110.

Robertson, L.; Farrell, D. and Highliffe, P.M. (1977): The isolation of Brucell amelitensis from contaminated sources. Brucella Vet. J., 133: 193-195.

Salem, A.A. and Hosein, H.I. (1990): Brucella strains prevalent in Egypt. Assiut Vet. Med. J. 22 (44) 160-193.

Samaha, H.; Al-Rowaily, M.; Khoudair, R.M. and Ashour, H.M. (2008): Multicenter Study of Brucellosis in Egypt. Emerg Infect Dis. 14(12) 1916-1918.

Samaha, H.; Mohamed, T.R.; Khoudair, R.M. and Ashour, H.M. (2009): Sero-diagnosis of Brucellosis in, Cattle and Humans in Egypt. Immunobiol., 214: 223-226.

SANCO (Scientific Committee on Animal Health and Animal Welfare)"Brucellosis in sheep and goats" C.2/AH/R23 (2001): Brucellosis in sheep and goats (brucella melitensis) scientific committee on animal health and animal welfare.

Sedeek, S.R. (1999): Serological studies on brucella infection in cattle sheep and goat in Assiut Governorate. Assiut Vet. Med. J. 42 (83) 216-227.

Tikare, N.V.; Mantur, B.G. and Bidari, L.H. (2008): Brucellarmeningitis in an infant - evidence for human breast milk transmission; J. Trop. Pediatr., 54: 272-274.

Uche, U.E. and Agbo, J.A. (1985): Bacterial isolates from Nsukka meat market: a zoonotic appraisal. Int. J Zoonosis 12(2)105-110.

Wright P.F. and Nielsen K.H (1990): Current and future serological methods. Advances in brucellosis research. P. 305-320. In L.G.Adams (ed). Texas A\&M. University press. 


\section{دراسة مدى تواجد الإصابة بالبروسيلا فى بعض المجترات المذبوحة خارج المجازر فى محافظة أسيوط \\ سيل حسن الهبتـي ، خالد أبوجازية ، محمود عمار محمد عمار \\ Email: mahmoud2014eg@yahoo.com}

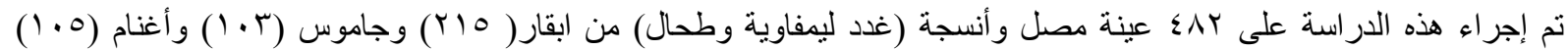

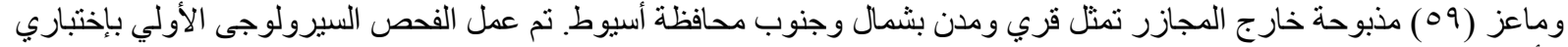

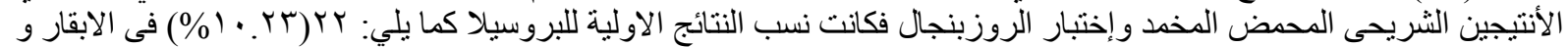

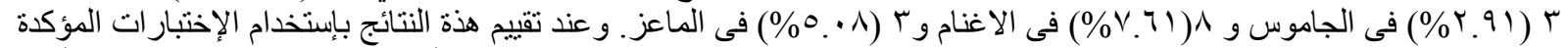

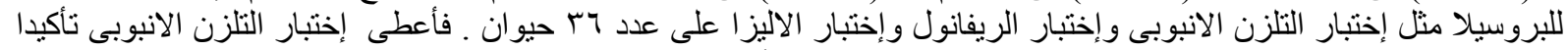

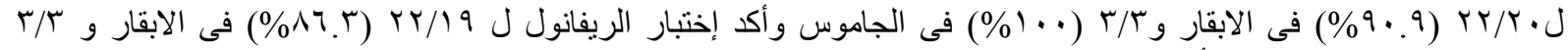

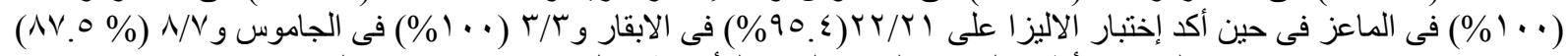

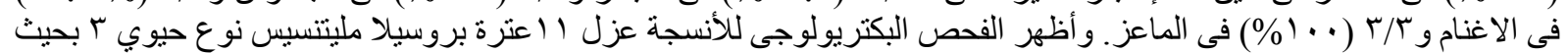

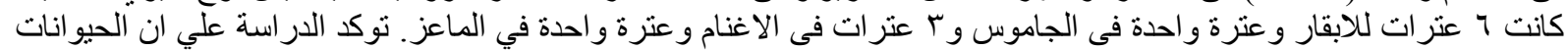

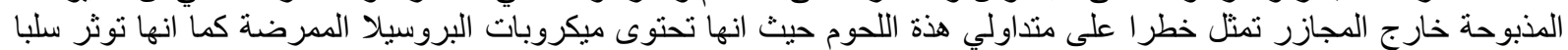
علي بر امج مكافحة البروسيلا. 